\title{
Species Diversity and Potential Utilization of Moraceae in Nglanggeran Ancient Volcano, Gunungkidul Regency, Yogyakarta
}

\author{
Reinatawas Febri Santika ${ }^{1}$, Ratna Susandarini ${ }^{1 *}$ \\ 1) Faculty of Biology, Universitas Gadjah Mada, Jl. Teknika Selatan, Sekip Utara, Yogyakarta, Indonesia, 55281
}

Submitted: 30 December 2019; Accepted: 28 July 2020; Published: 15 December 2020

\begin{abstract}
Nglanggeran Ancient Volcano is one of the ecotourism areas in Gunungkidul Regency, Yogyakarta. This ancient volcano is one of the geological sites in Pegunungan Sewu. Pegunungan Sewu is a National Geopark in Indonesia and has been designated as a UNESCO Global Geopark since 2015. The determination of an area into a National Geopark and Global Geopark makes the biodiversity in the area must be protected and preserved, including the plant diversity, one of which is Moraceae. The ecological and economic importance of Moraceae in Nglanggeran Ancient Volcano has not been documented properly. This fact encourages the need to do this research. The aim of this research was to record species diversity of Moraceae and its potential uses. The research was conducted in August-November 2019 at Nglanggeran Ancient Volcano and followed by data analysis in Plant Systematic Laboratory, Faculty of Biology, Universitas Gadjah Mada. The samples were collected at two different tracks, covering the track to the peak and the pathway down. There were six species found, namely Artocarpus altilis (Parkinson) Fosberg, Artocarpus beterophyllus Lam., Ficus benjamina L., Ficus septica Burm. f., Maclura cochinchinensis (Lour.) Corner, and Streblus taxoides (Roth) Kurz. The potential uses of Moraceae by local people were identified from the interview and enriched by data from literature studies indicated that Moraceae plants were used as a food, medicine, for construction, soil protection plants, and houseplant.
\end{abstract}

Keywords: Moraceae, Nglanggeran Ancient Volcano, Plant potential uses, Species diversity

\section{INTRODUCTION}

Nglanggeran is an ancient volcano and a popular historic geological site in Pegunungan Sewu renowned as one of the ecotourism areas in Gunungkidul Regency, Yogyakarta. Pegunungan Sewu is a National Geopark in Indonesia and has been designated as a UNESCO Global Geopark since 2015 (Ministry of Energy and Mineral Resources, 2018). The concept of Geopark which was initiated by UNESCO applies a sustainable regional development concept that integrates three aspects of diversity, namely geodiversity, biodiversity, and cultural diversity. This concept aims at developing the economy of local communities based on the protection of the three diversities (UNESCO, 2014; Ministry of Energy and

\footnotetext{
*Corresponding author

Email: ratna-susandarini@ugm.ac.id

(C) 2020, J. Tropical Biodiversity Biotechnology (CC BY-SA 4.0)
}

Mineral Resources, 2018). In this study, biological diversity is the main focus as presented as the inventory of species diversity. The cultural diversity aspect was observed by documenting the utilization of Moraceae species by local people. Meanwhile, the geological diversity aspect is not examined in this study because it is not under the scope and competence of the authors.

The determination of an area into a National Geopark and Global Geopark makes the biodiversity in the area must be protected and preserved, including the plant diversity, one of which is Moraceae. Moraceae is a family of Angiosperm consisted of 37 genera and approximately 1.100 species, with Ficus being the largest genus within the family with 600 species (Singh, 2010). Moraceae are distributed in tropics, subtropics, and temperate regions (Clement \& Weiblen, 2009; Singh, 2010). Ficus has a critical ecological function in tropical rainforest ecosystem, also as an important food 
source for a wide range of frugivores (Datwyler \& Weiblen, 2004; Harrison, 2005). The family is important for its fruits such as mulberry (Morus alba L., Morus nigra L.), fig (Ficus carica L.), and breadfruit (Artocarpus altilis (Parkinson) Fosberg). Leaves of Morus are widely known for rearing silkworms (Singh, 2010). The ecological and economic importance aspects of Moraceae in Nglanggeran Ancient Volcano have not been documented properly. This fact encourages the need to do this research. The aim of this research was to record species diversity of Moraceae and their potential uses, which covers the biological and cultural diversity aspects of geopark concept, whereas geological diversity was not included in this study due to the reasonable consideration of being out of the author's competence.

\section{MATERIALS AND METHODS}

\section{Materials}

The materials used in this study were plant samples collected from two different tracks of Nglanggeran, alcohol 70\%, specimen label, plastic bags, herbarium envelope, herbarium sheet, and newspaper. The tools used in this study were garden scissors, cutter, oven, sprayer, digital camera NIKON J5, smartphone, GPS (Global Positioning System), altimeter, rope, board, cardboard, and identification books. Data on the potential use of Moraceae species was gathered using questionnaires collected from local people by the assistance of POKDARWIS (working group for tourism).

\section{Methods}

Plants specimens were taken from its natural population along two different tracks, covering the track to the peak and the pathway down (Figure 1). The specimens were documented by taking the photograph of the whole plant and its habitat before being preserved into dried herbarium specimens. Identifications were carried out based on the morphological character using an online database (Digital Flora of Eastern Ghats, Kew Herbarium Catalogue, Useful Tropical Plants Database) and identification books (Flora of Java, Flora Malesiana). Data on potential use and current utilization of Moraceae plants was obtained by gathering the information from the local community using a simple questionnaire and enriched with information from relevant literature. There were four questions in the questionnaire asked the local people, namely: (1) whether local people are allowed take plants in the tourist area or not; (2) what species commonly used by local people; (3) what plant parts that are usually used by local people; and (4) what is the common utilization of the plants by local people. The results obtained were presented as species descriptions and information on their potential uses.

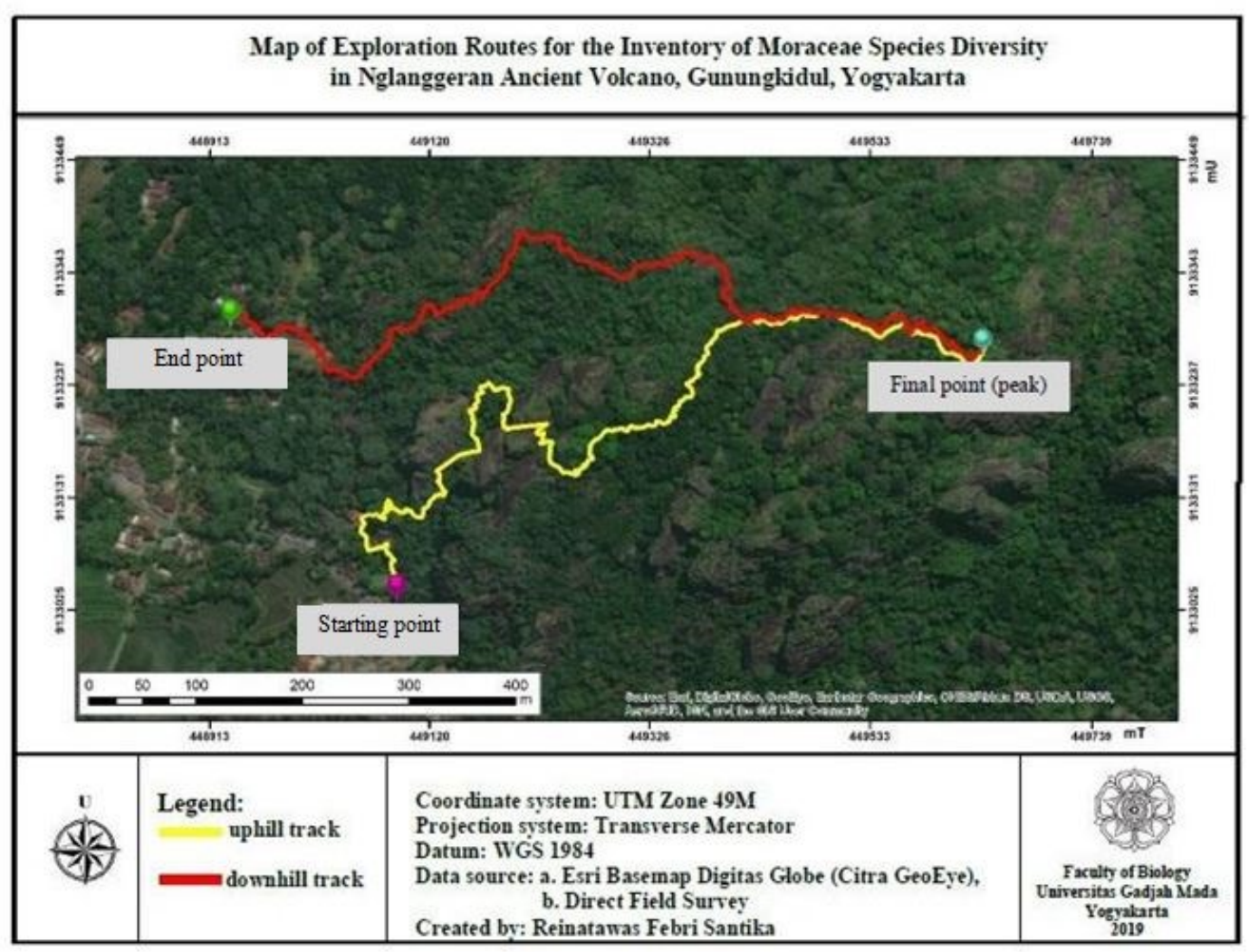

Figure 1. Tracks of specimen collection in Nglanggeran Ancient Volcano 

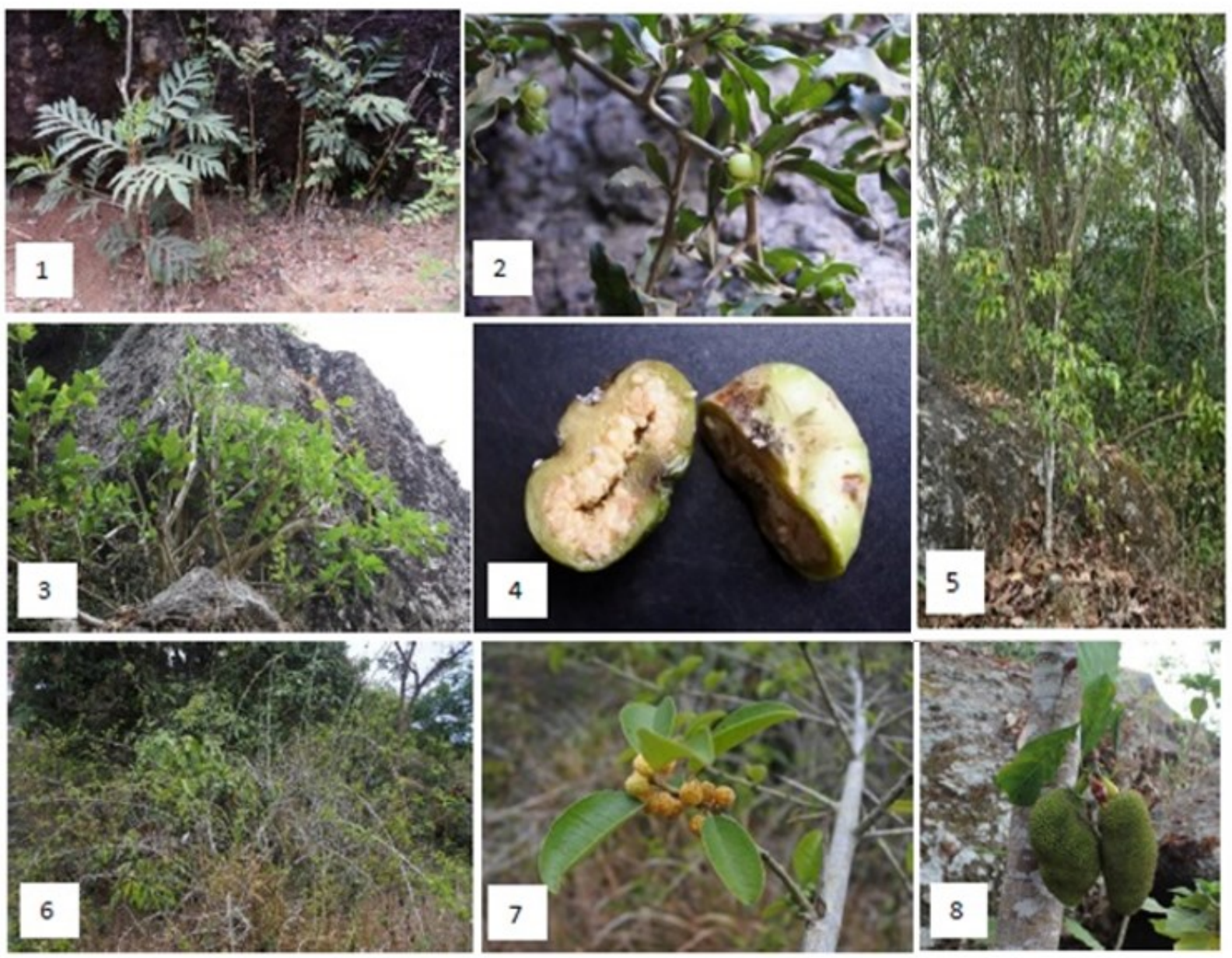

Figure 2. Species of Moraceae found in Nglanggeran were A. altilis (1), S. taxoides (2), F. septica habit (3), F. septica inflorescences (4), F. benjamina (5), M. cochinchinensis habit (6), M. cocbinchinensis inflorescences (7), $A$. beterophyllus (8).

\section{RESULTS AND DISCUSSION}

Six species consisted of four genera of Moraceae were found during field exploration in Nglanggeran Ancient Volcano area (Figure 2). These species were Artocarpus altilis (Parkinson) Fosberg, Artocarpus beterophyllus Lam., Ficus benjamina L., Ficus septica Burm. f., Maclura cochinchinensis (Lour.) Corner, and Streblus taxoides (Roth) Kurz.

A previous study by Widodo and Luthfi (2017) found 10 species of Moraceae in Nglanggeran Ancient Volcano, namely Fatoua sp., Morus sp., Malaisia scandens (Lour.) Planch., Streblus asper, S. taxoides, M.cochinchinensis, F. benjamina, F.septica, F. montana Burm. f., and Artocarpus integra (Thunb.) Merr. Results of this exploration showed that there were only six species found (Figure 2), namely $A$. altilis, $A$. beterophyllus, F. benjamina, F. septica, $M$. cochinchinensis, and S. taxoides.

The difference in the number of species found can be due to differences in exploration scope areas or exploration tracks, the presence of plants in areas that were too dangerous to explore (such as steep slope), and the difference of season when explorations were carried out. The six species found during the course of study was ranging from the lowest with only two individuals for $S$. asper, three for $A$. altilis, four for $A$. beterophyllus, five for $F$. septica, and eleven individualsfor both F. benjamina and $M$. cocbinchinensis.

The results of this study showed that species diversity of Moraceae in Nglanggeran ancient volcano was low, as indicated by only six species was found. This number is notably lower compared to similar studies by Widodo and Lutfi (2017) who obtained 10 species of Moraceae in Nglanggeran. When compared to other locations, the number of Ficus species obtained in this study was only two, much lower than similar studies conducted in Prof. Soemitro Djojohadikusomo Conservation Forest West Sumatra which found 20 Ficus species (Nur'aini et al., 2013). A study by Rahadiantoro and Siahaan (2016) on the diversity of Moraceae tree species in Telogo Dowo, Sempu Island recorded 14 species. The number of Ficus species found in this study was also very small compared to that obtained by Almulqu et al. (2018) in Mutis Timau Protected Forest, East Nusa Tenggara. Based on these comparisons, the diversity of Moraceae species in 
Nglanggeran ancient volcano revealed in this study was obviously low.

The six species found in this study were collected from their habitat at the elevation 200-700 mdpl. Artocarpus altilis and Artocarpus heterophyllus were found at $200 \mathrm{mdpl}$, and these two species were also known planted by local people in their yard. Ficus benjamina was mostly found near the rocky karst areas at 200-670 mdpl. Ficus septica also found in similar habitat at 200-460 mdpl. Maclura cocbinchinensis was found at 200-638 mdpl, while Streblus taxoides was found at $460 \mathrm{mdpl}$. The Morphological description of these six species was presented below.

\section{Artocarpus altilis}

An evergreen tree that is monoecious with heights up to 15-20 m, smooth bark, may reach a height of 4 $\mathrm{m}$ before branching, two large stipules enclosing the terminal bud, up to $30 \mathrm{~cm}$, yellowing and falling when leaves fold or inflorescences emerge. Leaves obovate to broadly ovate, spirally arranged, thick leaves, leathery, margin entire, acuminate apex, top dark green, often glossy, pale green and dull underside with an elevated midrib and main veins. Mature leaves pinnatipartite with 3-8 segments, while juvenile leaves on young trees and new shoots of mature trees usually larger, more dissected, and more hirsute. Leaves sometimes smooth but often with few reddish hairs on midrib and veins. Male inflorescences have yellow, cylindrical, $7-30 \mathrm{~cm}$ lengths, composed of hundreds of flowers attached to the spongy core. Male flowers have a tubular calyx, apically 2-lobed, and elliptic anthers. Female flowers have a tubular calyx, ovary ovoid, long styled, and apically 2-branched. The fruit has a highly specialized structure, a syncarp, composed of 15002000 flowers attached to the fruit axis or core. Fruit globose to oblong, light green rind, yellowish-green or yellow when mature, flesh creamy white or pale yellow, seedless, but some forms seeded, seeds have a thin dark-brown outer skin (thick $\pm 0,5 \mathrm{~mm}$ ) (Zhekun \& Gilbert, 2003; Orwa et al., 2009a).

\section{Artocarpus heterophyllus}

An evergreen tree with heights up to $8-25 \mathrm{~m}$, straight stemmed, branching near the base, canopy dense, and dome-shaped. Bark is greyish-brown, rough, and sometimes scaly, all living parts of the tree exude white latex when injured. Leaves are elliptic to obovate, glossy, dark green top, pale green or light green underside, entire margin, blunt apex, cuneate or pointed base, alternately arranged on horizontal branches, spirally arranged on ascending branches. An individual flower is attached on an elongated axis and forming a raceme inflorescence. Male inflorescences have oblong, cylindrical, or clavate with $2-7 \mathrm{~cm}$ length, peduncle $1-5 \mathrm{~cm}$, yellowish, sterile flower has solid perianthium, fertile flower is tubular, and bi-lobed. Female inflorescence have oblong or cylindrical, rough, light to dark green skin, 5-15 cm length. Fruiting syncarp, pale yellow when young, yellowish-brown when mature, ellipsoid, globose, or irregularly shaped, covered by a rubbery rind and hard pyramidal, pointed or blunt spines. Syncarp composed of many fertilized ovaries developed into a yellow fruitlet. Unfertilized female flower developed into a hard strap or string-like structure, has white color, filling the space between fruitlets, called perigones. Seeds are oval-oblong or oblong-ellipsoid (Zhekun \& Gilbert, 2003; Haq, 2006; Orwa et al., 2009b).

\section{Ficus benjamina}

A monoecious, tree or strangler, hemi-epiphytic, with height up to $35 \mathrm{~m}$ high, producing aerial roots, and have brown to greyish bark. Leaves spirally arranged with lamina elliptic, oblong, to ovate, acuminate apex, rounded to obtuse base, entire margin. Inflorescence hypanthodium, there are male, female, and gall flowers within the same inflorescence. Male flower has short pedicellate and long filament. Female flower is sessile with 3 calyx lobes, short style, and enlarged stigma. Gall flower has 3-5 calyx lobes, ovoid ovary, and short style. Infructescences is syconium, yellow to orange or dark red when mature (Zhekun \& Gilbert, 2003; Berg et al., 2006).

\section{Ficus septica}

A dioecious Tree or shrub with yellowish latex and pale brown to yellowish-brown bark. Branchlets are thick and cylindric. Red stipules, ovate to lanceolate, with $2-3 \mathrm{~cm}$ length, and membranous. Leaves are alternate, lamina oblong, ovate-elliptic, or obovate, acuminate, mucronate, or sometimes caudate apex with base cuneate, and entire margin. Inflorescence hypanthodium, there are male, female, and gall flowers within the same inflorescence. Male flower near apical pore has 2 or 3 calyx lobes, 1 stamen, short filament, and ellipsoid anther. Female flower has long pedicellate, 2 or 3 calyx lobes, long style, and clavate stigma. Gall flower has short and transparent calyx lobes, ovoid to globose ovary, and short style. Infructescences syconium, green to light brown, has white small spots in rind, apical pore open when mature (Zhekun \& Gilbert, 2003; Berg et al., 2006).

\section{Maclura cochinchinensis}

An evergreen shrub that has long branches, dioecious, erect, or scandent. Branches are brown greyish, with $4 \mathrm{~cm}$ long straight or curved thorns. 
Lamina is elliptic-lanceolate to oblong, apex shortly acuminate to subacute, base obtuse, rounded, or cuneate, and entire margin, spirally arranged. Female and male inflorescences are capitulum with a diameter of $0,4-1 \mathrm{~cm}$. Male flower has 4 calyx lobes, and short anthers. Female flower did not have calyx lobes, basally connate. Fruiting syncarp with a diameter of $2-5 \mathrm{~cm}$, orange-reddish when mature (Zhekun \& Gilbert, 2003; Berg et al., 2006)

\section{Streblus taxoides}

An evergreen shrub with heights up to $5 \mathrm{~m}$, dioecious, much-branched, with thorns up to $1,5 \mathrm{~cm}$ long. Lamina is elliptic to oblong-lanceolate, acuminate to blunt apex, base is acuminate to obtuse, and entire margin. Male inflorescences spike or raceme, sessile. Male flower has short pedicellate, 4 calyx lobes, and globose anthers. Female flower is solitary, sometimes clustered, 4 calyx lobes, and apically style branched. Drupes globose, at first enclosed by enlarged calyx lobes (Zhekun \& Gilbert, 2003; Berg et al., 2006).

The fruit of Artocarpus altilis (breadfruit) is used as food and source of carbohydrates. Young and ripe fruit of Artocarpus heterophyllus (jackfruit) is also used as food and its seeds are sometimes boiled or roasted for food. Leaves of breadfruit and jackfruit are used as animal feed. Their trunk is used for construction material (Berg et al., 2006).

Extracts and metabolites of breadfruit leaves, stems and fruit contain various useful active compounds such as antibacterial, anti-inflammatory, anti-diabetic, antifungal, and antioxidant activity (Sikarwar et al., 2014). Jackfruit root extract is used to treat skin diseases, asthma, and diarrhea. Its leaf extract contains flavonoids, anthocyanin, tannins, and proanthocyanidin which can increase glucose tolerance in diabetic patients (Haq, 2006). Ficus benjamina has potential uses as a medicinal plant, including its fruit extracts and latex which were used to treat skin diseases, inflammation, malaria, as antimicrobial, antinociceptive, antipyretic, hypotensive, and anti-dysentery (Imran et al., 2014). Ficus septica is used as traditional medicine for fever, headache, and stomach-ache (Ueda et al., 2009). Ficus septica also has been reported as having cytotoxic activity against HONE-1 nasopharyngeal cancer cells and gastric cancer cells NUGC (Damu et al., 2005). Maclura cocbinchinensis wood can be used to treat for fever (Atika \& Salma, 2017). Streblus taxoides root is used to treat glandular swellings, and its trunk is used to treat elephantiasis (Kadavul \& Divit, 2008).

Jackfruit has a function as a shade tree and can reduce the impact of rainfall on the soil. They are sometimes also planted on slopes and hills to help control soil erosion. The widespread root system can help the absorption of groundwater, and therefore reduce flooding (Haq, 2006). Intensive growth of Ficus benjamina roots can damage roads and sidewalks so it is less suitable as a shade plant on the roadside (Gilman \& Watson, 2011). Ficus benjamina is widely cultivated as an ornamental plant. In Indonesia, Streblus taxoides are used for bonsai, but their use is already rare (Sulistyo, 2008). Maclura cocbinchinensis woods are used as batik dye along with bark of Ceriops tagal and Peltophorum pterocarpum to make soga colors (Atika \& Salma, 2017).

\section{CONCLUSION}

Species diversity of Moraceae in Gunung Api Purba Nglanggeran is low based on comparison to other studies, either those from the same area or other regions in Indonesia. Six species were found in this study namely Artocapus altilis, Artocarpus heterophyllus, Ficus benjamina, Ficus septica, Maclura cocbinchinensis, and Streblus taxoides. The potential uses of Moraceae are food, medicine, for construction, soil protection plants, and houseplant.

\section{ACKNOWLEDGMENTS}

The authors wish to express their sincerest gratitude to POKDARWIS Nglanggeran, Gunungkidul for their help in facilitating this study.

\section{REFERENCES}

Almulqu, A.A., Arpornpong, N., Boonyanuphap, J., 2018. Tree species composition and structure of dry forest in Mutis Timau Protected Forest Management Unit of East Nusa Tenggara, Indonesia, Biodiversitas 19: 496-503. DOI: 10.13057/biodiv/d190217.

Atika, V. and I. R. Salma, 2017, Extract the coloring Quality Wood Tegeran (Cudrania javanensis) on Batik, Dynamics Crafts and Batik [Kualitas Perwarnaan Ekstrak Kayu Tegeran (Cudrania javanensis) pada Batik, Dinamika Kerajinan dan Batik], 34(1):11-18.

Berg, C. C., E. J. H. Corner, F. M. Jarret, 2006, Moraceae: Genera other than Ficus, Flora Malesiana Volume 17 Part 1.

Clement, W. L. and G. D. Weiblen, 2009, Morphological evolution in the mulberry family (Moraceae), Systematic Botany 34(3):530552.

Damu, A. G., P. Kuo, L. Shi, C. Li, C. Kuoh, P. Wu, T. Wu, 2005, Phenanthroindolizidine Alkaloids from The Stems of Ficus septica, J. Nat. Prod. 68(7):1071-1075. 
Datwyler, S. L. and G.D. Weiblen, 2004, On the origin of the fig: phylogenetic relationship of Moraceae from $n d b F$ sequences, American Journal of Botany 91:767-777.

Gilman, E. F. and D. G. Watson, 2011, Ficus benjamina: Weeping Fig, IFAS Assessment of the Status of Non-Native Plants in Florida's Natural Areas, viewed 01 Desember 2019, from http://plants.ifas.ufl.edu/

Haq, N, 2006, Jackfruit, Artocarpus beterophyllus, Southampton Centre for Underutilised Crops, Southampton, p. 22-23, 28, 72-73.

Harrison, R.D, 2005, Figs and the diversity of tropical rainforests, Bioscience 55(12):1053-1064.

Imran, M., N. Rasool, K. Rizwan, M. Zubair, M. Riaz, M. Zia-Ul-Haq, U. A. Rana, A. Nafady, H. Z. E. Jaafar, 2014, Chemical Composition and Biological Studies of Ficus benjamina, Chemical Central Journal 8:12.

Kadavul, K. and A. K. Divit, 2008, Ethnomedical Studies of The Woody Species of Kalrayan and Shervarayan Eastern Ghats, Tamil Nadu, Indian Journal of Traditional Knowledge 8(4):592597.

Ministry of Energy and Mineral Resources [Kementerian Energi dan Sumber Daya Mineral], 2018, Geopark Increases Participation, and Income of Surrounding Communities [Geopark Tingkatkan Partisipasi, dan Pendapatan Masyarakat Sekitar], viewed 01 Mei 2019, from www.esdm.go.id.

Nur'aini, Syamsuardi, Arbain, A., 2013, Plant Ficus L. (Moraceae) in forest conservation Prof. Soemitro Djojohadikusumo, [Tumbuhan Ficus L. (Moraceae) di hutan konservasi Prof. Soemitro Djojohadikusumo], PT. Tidar Kerinci Agung (TKA), Sumatera Barat, Jurnal Biologi Universitas Andalas 2(4): 235-241.

Orwa C., A. Mutua, Kindt R., Jamnadass R., S. Anthony, 2009a, Artocarpus altilis, Agroforestree Database: a tree reference and selection guide version 4.0 , viewed 15 November 2019, from http:// www.worldagroforestry.org/
Orwa C., A. Mutua, Kindt R., Jamnadass R., S. Anthony, 2009b, Artocarpus beterophyllus, Agroforestree Database: a tree reference and selection guide version 4.0, viewed 18 November 2019, from http:// www.worldagroforestry.org/

Rahadiantoro, A. and Siahaan, F.A, 2016, The diversity of tree species in the forest familia Moraceae around Waru-Waru - Telogo Dowo, Sempu Island KKeragaman jenis-jenis pohon familia Moraceae di hutan sekitar Waru-Waru Telogo Dowo, Pulau Sempu], Prosiding Seminar Nasional Biodiversitas VI, Surabaya 3 September 2016: 23-30.

Sikarwar, M.S., B. J. Hui, K. Subramaniam, B. D. Valeisamy, L. K. Yean, and K. Balaji, 2014, A Review on Artocarpus altilis (Parkinson) Fosberg (breadfruit), Journal of Applied Pharmaceutical Science 4(08):91-97.

Singh, G, 2010, Plant Systematic: An Intergrated Approach 3rd edition, CRS Press, Boca Raton, p. 590-592.

Sulistyo, B., 2008, Tropical Bonsai Gallery, Niaga Swadaya, Depok, p. 211.

Ueda, J., M. Takagi, K. Shin-ya., 2009, Aminocaprophenone- and Pyrrolidine-Type Alkaloids from the Leaves of Ficus septica, Journal of Natural Products 72 (12):2181-2183.

UNESCO, 2014, What is a UNESCO Global Geopark? viewed 01 Mei 2019, from http:// www.unesco.org.

Widodo and M. J. Luthfi, 2017, Checklist of flowering plants (Magnoliophyta) of Mount Nglanggeran, Gunungkidul: Confirmation and Update of Flora of Java and APG III, Biology, Medicine, and Natural Product Chemistry 6(1):1936.

Zhekun Z. and M. G. Gilbert, 2003, Moraceae, In: Flora of China: (Ulmaceae through Basellaceae) (Wu Z., P.H. Raven and D.-Y. Hong, eds.) 5: 21- 73. Science Press, Beijing, and Missouri Botanical Garden Press, St. Louis, USA. 